\title{
Ecology and systematics of a new species of Uromunna (Crustacea: Isopoda) from Spanish eelgrass beds
}

\author{
Patricia Esquete · George D. F. Wilson • \\ Jesús S. Troncoso
}

Received: 5 November 2013/Revised: 20 March 2014/Accepted: 24 March 2014/Published online: 9 April 2014 (c) Springer-Verlag Berlin Heidelberg and AWI 2014

\begin{abstract}
Uromunna naherba sp. nov. is described from eelgrass beds (Zostera marina and Z. noltii) of the NW Iberian Peninsula. This is the second species of the genus reported from the NE Atlantic, after $U$. petiti. The new species was more abundant on rhizomes than on the leaves of the plants. Seasonal samples show that ovigerous females are present throughout the year, but become more abundant in late spring and summer, when adult males decrease in frequency. Ovigerous females appear in only one size class. Owing to the yearly productivity cycle of the eelgrasses, these data suggest that the species is semelparous and completes its lifecycle within 1 year. The taxonomic characters of the genus are discussed.
\end{abstract}

Keywords Zostera - Iberian Peninsula Atlantic .

Population $\cdot$ Munnidae $\cdot$ Asellota

\section{Introduction}

Seagrass meadows constitute complex habitats that favor the settlement and maintenance of high benthic species diversity in temperate and tropical waters. Eelgrasses, in particular, have a great capacity to provide food resources,

Communicated by H.-D. Franke.

P. Esquete $(\bowtie) \cdot$ J. S. Troncoso

Departamento de Ecología y Biología Animal, Universidad de

Vigo, Campus As Lagoas-Marcosende, 36310 Vigo, Pontevedra,

Spain

e-mail: pesquete@uvigo.es

G. D. F. Wilson

Australian Museum, 6 College Street, Sydney, NSW 2010,

Australia substrate and shelter to many taxonomic groups (Fredette et al. 1990; Boström and Mattila 1999; Hasegawa et al. 2008). Recent sampling of peracarid crustaceans in Spanish seagrass habitats (Esquete et al. 2011) found several species of the asellotan isopod family Munnidae. Species of Munnidae have been described or reported in eelgrasses, such as Uromunna brevicornis (Thomson, 1946) (Poore 1984), Uromunna peterseni (Pires, 1985), Uromunna reynoldsi (Frankenberg and Menzies, 1966) (Kensley et al. 1995). In ecological studies, munnids are often mentioned only to generic level, owing to a lack of adequate identification tools.

The family Munnidae Sars 1897 has representatives in all marine and estuarine environments from the shallow littoral to the deep sea. Uromunna Menzies, 1962 is a circumtropical genus that occurs in temperate and tropical waters in both hemispheres (Poore 2002). Most species of Uromunna live in shallow, brackish waters, where they can be locally found in high densities (e.g. Esquete et al. 2011). Nevertheless, the geographic distribution of Uromunna species still is poorly known, most records being restricted to the species' type locality. The small size of the individuals $(<2 \mathrm{~mm}$ length in most species) and the methodology of benthic studies, frequently using larger mesh sizes, often exclude tiny Uromunna species from appearing in the samples. To date, the only species of the genus reported by ecologists in the NE Atlantic was Uromunna petiti Amar, 1948, on the Atlantic side of the Strait of Gibraltar (Castello and Carballo 2001).

The status of the various genera within the Munnidae has been frequently discussed. Specifically, the genus Uromunna was described by Menzies (1962) as a subgenus, basing on the leaf-like, spineless ventral uropodal ramus of certain species included in Munna Krøyer 1839. 
Subsequently, Kussakin (1962) and Frankenberg and Menzies (1966) revised the subgenus by adding new characters, and Kensley (1980) discussed the utility of these and the validity of the subgenera of the genus Munna. Finally, Poore (1984) transferred Uromunna to generic rank, providing a list of species and a new diagnosis. In the present work, a new species of Uromunna is described from seagrass beds of NW Spain. Defining characters as well as the other species to be included in the genus are discussed. The ecology and seasonal dynamics of the population structure are described with preliminary remarks on the species' life cycle.

\section{Materials and methods}

Field and laboratory methodology

O Grove (NW Iberian Peninsula; $42^{\circ} 41^{\prime}-42^{\circ} 28^{\prime} \mathrm{N} 9^{\circ} 01^{\prime}-$ $8^{\circ} 44^{\prime} \mathrm{W}$ ) is an estuarine, sheltered inlet that is seasonally influenced by high precipitation and freshwater input from several streams during autumn/winter. Its sandy and muddy bottoms are covered by the eelgrasses Zostera marina (L.) and Z. noltii Hornem. In December 1996, benthic samples were taken in $\mathrm{O}$ Grove inlet using a Van Veen grab to characterize the macrofaunal assemblages inhabiting these meadows. Five replicate samples were taken at ten sites, representing a total sampled area of $0.28 \mathrm{~m}^{2}$ for each site. An additional sample was taken on each site for granulometric, calcium carbonate and organic matter content analyses.

One of the sites located at the center of the inlet (site D27) was selected to study seasonal variation. Samples were taken bimonthly between May 1998 and March 1999 by scuba divers. At each sampling date, five replicate quadrats of $0.0625 \mathrm{~m}^{2}$ were harvested of sea grass; the shoot and rhizome fractions were kept separately in plastic bags. One additional sample of sediment was taken per month of study for granulometric analyses and to determine calcium carbonate and organic matter content. Salinity, $\mathrm{pH}$ and temperature were measured in situ. Samples destined to faunal analyses were sieved through a $0.5-\mathrm{mm}$ mesh and fixed in $10 \%$ buffered formalin for later sorting and identification in the laboratory.

Sorted specimens were preserved in $70 \%$ ethanol. Due to the relatively large mesh size used in this study $(0.5 \mathrm{~mm}$ diameter), juvenile stages were not retained in the samples. Therefore, all measurements and population data obtained refer exclusively to adults.

For taxonomic data, line drawings were prepared using a camera lucida connected to a microscope. The total length (TL, defined as the distance from the frontal margin to the end of the pleotelson) of all individuals of the seasonal variation study was measured using an ocular micrometer in a stereo microscope.

Statistical analyses

Correlations between environmental variables and size as well as density of the specimens were tested by means of Pearson's correlation coefficient (Zar 1999). Because normality of the size distributions could not be confirmed by Kolmogorov-Smirnov tests, nonparametric tests were applied to detect differences in the total lengths (Zar 1999): A Krustal-Wallis test was used to confirm differences in the TL between the following categories: males, nonovigerous females and ovigerous females. A Mann-Whitney rank was used to evaluate differences in the size of the specimens on the leaves and the rhizome fractions; seasonal variations in TL were tested separately for the above three categories by Krustal-Wallis tests; significance was assessed at $\alpha=0.05$ in all cases.

Systematics

Morphological terminology follows Just and Wilson (2004). The diagnoses and description were generated from a DELTA database (Dallwitz 1980; Dallwitz et al. 2000) and subsequently edited for clarity of language. In the descriptions, ratios are expressed as an equation: The first term equals the ratio multiplied the second term; the equals and multiplicative symbols are assumed. This format as well as the structuring of the descriptions is discussed in detail in Wilson (1989:16). Illustrations were performed using a compound microscope connected to a camera lucida and digitalized with a graphic tablet using Adobe Illustrator version 7.01. (Coleman 2003).

The holotype and two female paratypes were deposited in the Museo Nacional de Ciencias Naturales, Madrid (MNCN). Further paratypes were deposited in the Australian Museum, Sydney (AM).

\section{Results}

Systematics

Order Isopoda Latreille

Suborder Asellota Latreille

Family Munnidae Sars

Uromunna Menzies

Munna (Uromunna) Menzies, 1962: 36; Kussakin, 1962: 68; Frankenberg and Menzies, 1966.

Munnoides Carvacho, 1977: 6.

Munna (Pangamunna) Schultz, 1979: 577.

Uromunna Poore, 1984: 70. 
Diagnosis

With characters of Munnidae (as defined by Wilson 1980). Head anterior margin and dorsal surface without robust setae; eyes present. Pereonites dorsal surface without robust setae; pereonites 1-2 lateral margin regularly convex. Pleotelson lateral margin without robust setae. Antennular flagellum individual article length greater than width, terminal article longer than wide. Mandibular palp if present, not reaching beyond incisor. Mandible right lacinia mobilis indistinguishable from remainder of spine row. Pereopod I not dimorphic, in males similar to females in robustness and length. Pereopods II-VII auxiliary claw present. Female operculum with elongate setae.

Species included

Uromunna ubiquita Menzies, 1952, type species. Munna acarina, Miller 1941; Uromunna biloba Kensley, 2003; Munna brevicornis Thomson, 1946; Munna cananeia Pires, 1985; Munnoides caribea Carvacho, 1977; Uromunna deodata Müller, 1993; Munna hayesi Robertson, 1978; Uromunna humei Poore, 1984; Munna mediterranea Pierantoni, 1916; Munna nana Nordenstam, 1933; Munna peterseni Pires, 1985; Munna petiti Amar, 1948; Uromunna phillipi Poore, 1984; Munna powelli Kensley, 1980; Munna reynoldsi Frankenberg and Menzies, 1966; Uromunna samariensis Wolff and Brandt, 2000; Munna santaluciae Gascón and Mañé-Garzón, 1974; Munna schauinslandi Sars, 1905; Uromunna serricauda Müller, 1992; Munna sheltoni Kensley, 1977; Munna (Metamunna) similis Fresi and Mazzella, 1971.

Uromunna naherba Esquete and Wilson sp. nov.

Etymology. $\mathrm{Na}$ herba means in Galician language "in the grass".

Type fixation. Holotype male, TL $1.2 \mathrm{~mm}$, MNCN 20.04/9142, here designated.

Type locality. Seagrass beds, O Grove inlet, NW Iberian Peninsula, Spain, $42^{\circ} 29.75^{\prime} \mathrm{N}, 8^{\circ} 50.25^{\prime} \mathrm{W}, 5.9 \mathrm{~m}$, mud with Zostera marina and Z. noltii, $5.9 \mathrm{~m}, 18$ December 1996, J.S. Troncoso.

Holotype. Adult male, TL 1.2 mm, MNCN 20.04/9142, coll. 18.12.1996, J.S. Troncoso, R1.D27.96.

Paratypes. $2+(\mathrm{MNCN} 20.04 / 9143), 3$ oิ $\hat{\sigma}$, dissected (AM P.88323.001), 2 วิธิ (AM P.88322), $42^{\circ} 27.25^{\prime} \mathrm{N}$, $8^{\circ} 51.25^{\prime} \mathrm{W}$, mud with Zostera marina and Z. noltii, $0.3 \mathrm{~m}$, May 19981 ㅇ, 2 ovigerous 우 (AM P.88321).42 $29.75^{\prime} \mathrm{N}$ $8^{\circ} 50.25^{\prime} \mathrm{W}$, mud with Z. marina, $5.9 \mathrm{~m}$, December 18 , 1996. Collected by J.S. Troncoso.

Other material. $10 \hat{\jmath} \widehat{\partial}, 42^{\circ} 29.01^{\prime} \mathrm{N} 8^{\circ} 50.25^{\prime} \mathrm{W}$, mud with Z. marina, $0.8 \mathrm{~m} ; 7$ ôे, 4 우, December 4, 1996; 79 ธิธิ, 29 우, 90 ovigerous 우, May 1998; 17 ืํ, 9 우, 5

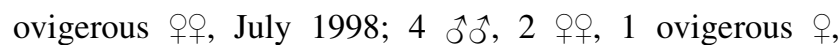

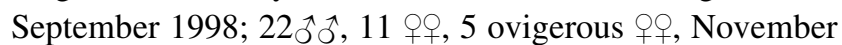

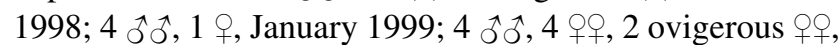
March 1999; all $42^{\circ} 29.75^{\prime} \mathrm{N} 8^{\circ} 50.25^{\prime} \mathrm{W}$, mud with $\mathrm{Z}$.

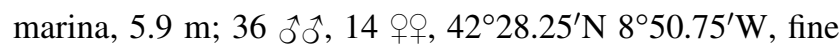
sand with Z. marina, $0.3 \mathrm{~m}$, December 11, 1996; 1 , 1 ovigerous $+42^{\circ} 27.75^{\prime} \mathrm{N} 8^{\circ} 50.25^{\prime} \mathrm{W}$, mud with $Z$. marina and Z. noltii, $0.3 \mathrm{~m}$, December 18, 1996; 9 ㅅ, 3 of , 1 ovigerous $q, 42^{\circ} 27.75^{\prime} \mathrm{N}, 8^{\circ} 51.75^{\circ} \mathrm{W}$, fine sand with $Z$.

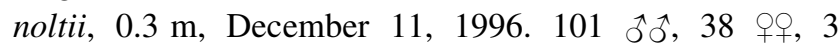
ovigerous $+42^{\circ} 27.25^{\prime} \mathrm{N} 8^{\circ} 52.25^{\circ} \mathrm{W}$, mud with $Z$. marina

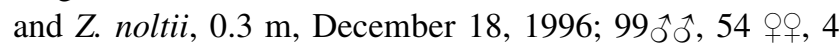
ovigerous $9 \circ, 42^{\circ} 27.25^{\prime} \mathrm{N} 8^{\circ} 51.25^{\circ} \mathrm{W}$, mud with $\mathrm{Z}$. marina and Z. noltii, $0.3 \mathrm{~m}$, December 18, 1996; 3 ô ô, $42^{\circ} 27.25^{\prime} \mathrm{N}$ $8^{\circ} 51.75^{\circ} \mathrm{W}$, mud with Z. marina and Z. noltii, $0.3 \mathrm{~m}$, December 18, 1996. All collected by J.S. Troncoso and logged in the collections of the laboratory of adaptations of marine animals (ADAM) of the University of Vigo (Spain).

Diagnosis. Pleotelson distal margin truncate. Head in both sexes length near pereonites 1-3 length, length 0.6-0.8 pereonites 1-4 length; anterior margin straight, without simple setae; preocular lobes distinct and projecting. Eye lobes both margins parallel; lobes in male anterior margin directed backward, in female parallel to frontal margin. Pereonite 2 in female lateral border sinuous, indented. Pleotelson distal margin truncate, lateral margins with denticles. Male pleopod I distal margin medial lobes convex. Male pleopod II protopod distolateral margin setae present.

Body (Figs. 1a-c, 2). Largest male length $1.3 \mathrm{~mm}$; length 2.3 width. Largest female length $1.5 \mathrm{~mm}$; female length 1.8 width.

Head (Fig. 1a-c). Length in male near pereonites 1-3 length, 0.8 pereonites $1-4$ length, width 1.0 first pereonite length. Length in female near pereonites 1-3 length, 0.6 pereonites 1-4 length, width 1.0 first pereonite length. Anterior margin straight. Preocular lobes distinct and projecting. Eyes present, ommatidia on eyelobe outer border, with more than 10 ommatidia, specifically 15-16 ommatidia. Eye lobes both margins parallel, dorsal margin without robust setae, in male anterior margin directed backward, in male posterior margin directed backward; in female anterior margin parallel to frontal margin, in female posterior margin directed backward.

Pereon (Fig. 1a-c). Pereon dorsal surface with few or no setae. All pereonites in male similar in width; all pereonites similar in length; pereonites 1-3 shoulders contiguous. Female body regularly oval; pereonites 2-4 distinctively longer than the rest; pereonites 1-3 in female shoulders contiguous; pereonite 2 in female lateral border sinuous, indented. Pereonites. Pereonite 7 width much narrower than pereonite 6 width, 0.8 pereonite 6 width, greater than pleotelson width. 


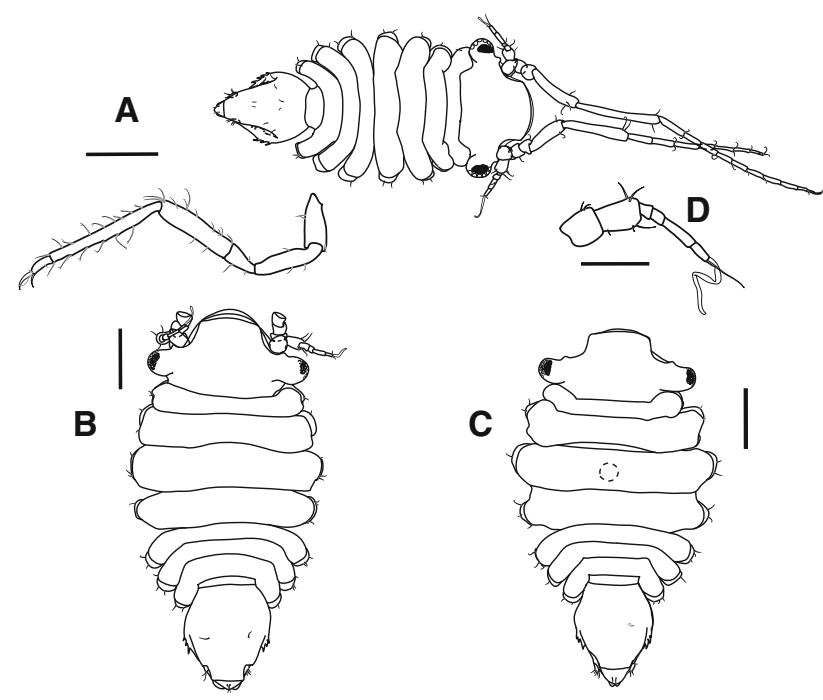

Fig. 1 Uromunna naherba sp nov. a Holotype MNCN 20.04/9142, male, habitus and pereopod VII; b female paratype MNCN 20.04/ 9143; c ovigerous female AM P.388321; $\mathbf{d}$ antennula. Scale bars $\mathbf{a}-$ c $0.2 \mathrm{~mm}, \mathbf{d} 0.1 \mathrm{~mm}$

Pleonites (Figs. 1a-c, 2). Pleonite 1 dimorphic; in male length 0.5 width; in female length 0.1 width.

Pleotelson (Figs. 1a-c, 2). Pleotelson length 1.3 width; pyriform; lateral margins denticles present, lateral margins denticles 3-4 on each side; distal margin truncate; without robust setae; dorsal simple setae present, arranged in pairs, 1-3 pairs in total; posterolateral margin at uropodal insertion smoothly curving, without concavity or indentation; suburopodal shelf absent.

Antennula (Fig. 1d). With one aesthetasc; distal tip reaching middle of antenna article 5, 0.7 head length. Antennula flagellum with 3 articles.

Antenna (Figs. 1a, 2a). About as long as the body, length 1.1 body length. Antenna flagellum longer than podomere articles 1-6, articles length greater than width, 10 articles in total, first segment about as long as more distal articles.

Mandible (Fig. 3a). Molar accessory hairs absent. Incisor process with four terminal and one subterminal cusps. Left lacinia mobilis with four cusps. Palp (Fig. 3b) present, not reaching beyond incisor, length 0.4 mandibular body length; second article without setae; terminal article twice as long as broad or more, curved, terminal article with 2 terminal setae. Other mouthparts. Labium (Fig. 3c) lobes with four spines. Maxillula (Fig. 3d) lateral lobe with 11 robust setae; medial lobe with 3 large setulose distal setae. Maxilla (Fig. 3e) lateral lobes with 3 distal setae; medial lobes with 9 setae. Maxilliped (Fig. 3f) endite distal border with 3 fan-shaped setae, 4 simple setae, no serrate robust setae, mesial border with 2 coupling hooks, dorsally with 2 plumose setae; epipod with setae, 4 in total.

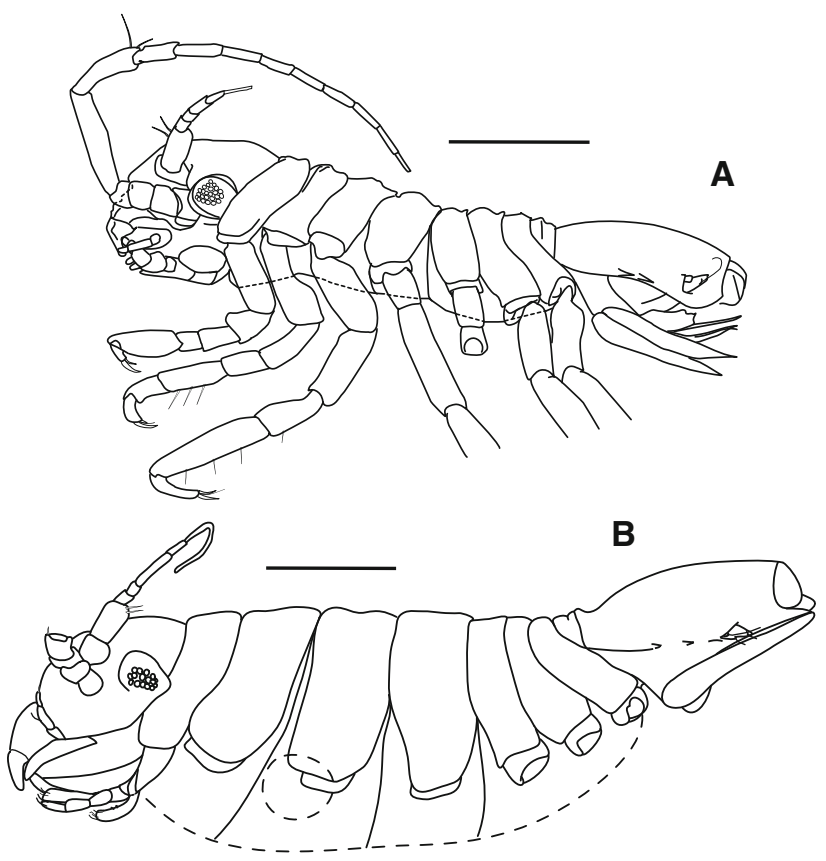

Fig. 2 Uromunna naherba sp nov. a Holotype (MNCN 20.04/9142) lateral view; b ovigerous female AM P.388321. Scale bars $0.2 \mathrm{~mm}$

Pereopods. Pereopod I (Fig. 4a, b) length 0.4 body length; carpus as long as wide; propodus robust setae present, 3 on proximal margin of palm; propodus palm cuticular fringe present. Pereopod II (Fig. 4c, d) not dimorphic, claw length approximately 6.0 basal width. Pereopods II-VII (Figs. 4c, d, 5) length 0.5, 0.6, 0.8, 0.8, $1.0,1.0$ body length, respectively, with ventral auxiliary claw, basal width half or more basal width of main claw. Pereopod VII ischium length greater than basis and merus lengths, carpus not elongate, length less than basis-merus lengths, propodus length near twice carpus length; propodus length 0.6 carpus length.

Penes. Inserted on pereonite 7 posterior margin and extending over pleonite 1. Distal margin well separated from proximal margin of pleopod I.

Male pleopods. Male pleopod I (Fig. 6a, b) distal margin medial lobes convex, lateral lobes approximately parallel; lateral lobes expansions absent. Male pleopod II (Fig. 6c) protopod length 2.6 width; distolateral margin setae present, lateral margin with 2 setae; distal margin tapering to narrow point; distal margin setae present, with 2 subdistal setae; endopod stylet roughly linear, projecting posteriorly, endopod stylet length 0.7 protopod length. Pleopod III (Fig. 6d) endopod lateral plumose seta much longer than other setae, inserting on lateral margin, well separated from medial plumose seta; exopod length less than endopod-protopod length, exopod width subequal to endopod width; exopod articulation distinct. Pleopod IV (Fig. 6e) exopod distal tip with one plumose seta. 


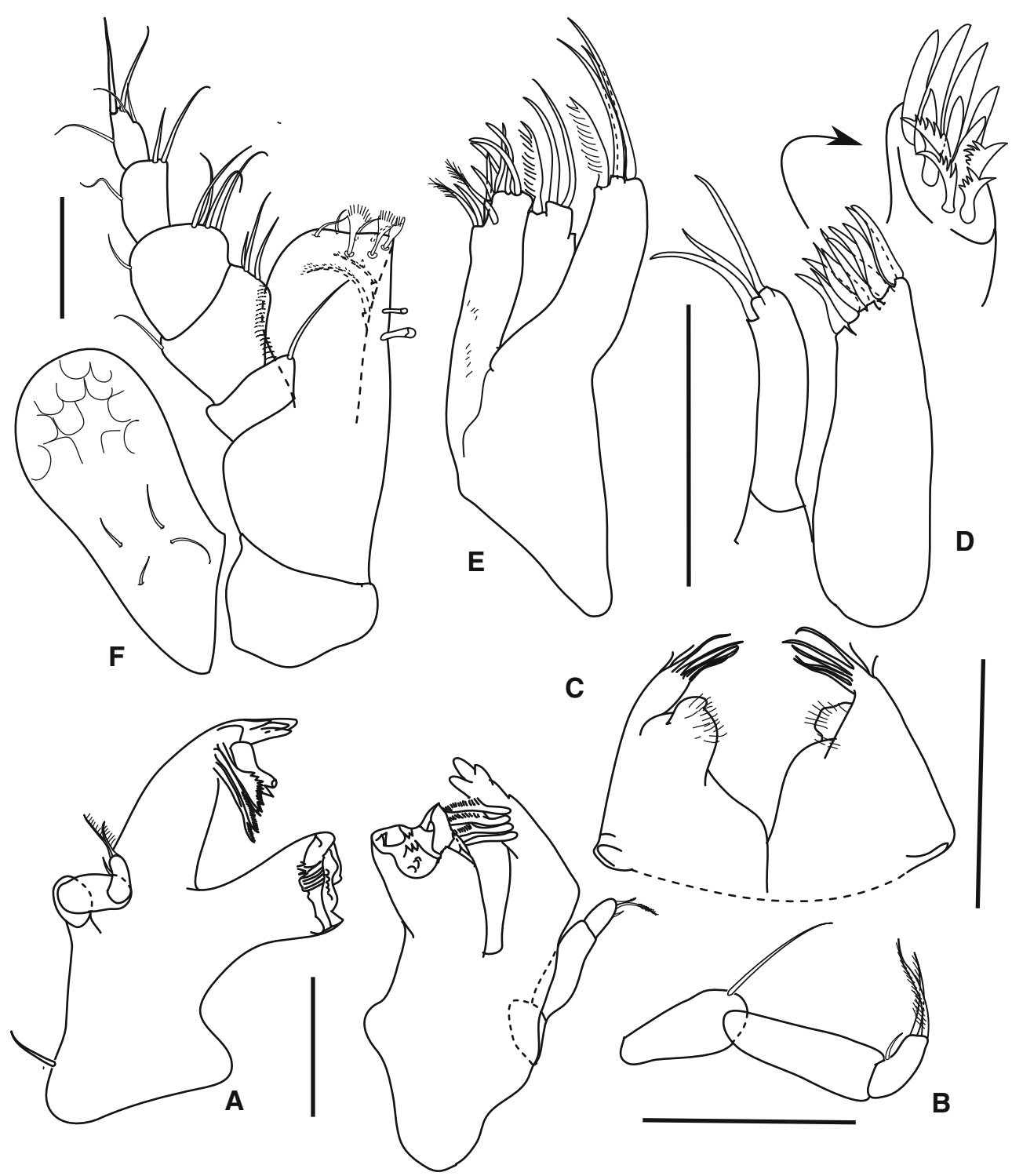

Fig. 3 Uromunna naherba sp nov, paratype AM P.88323.001. a Mandibles; b mandibular palp; c labium; d maxilla I; e maxilla II; f maxilliped. Scale bars $\mathbf{a}, \mathbf{b}, \mathbf{d}-\mathbf{f} 0.05 \mathrm{~mm}, \mathbf{c} 0.2 \mathrm{~mm}$

Female operculum (Fig. 7a). As long as wide, with one pair of subterminal elongate setae.

Uropods (Fig. 7b). Biramous, exopod present, protopod not visible in dorsal view, exopod visible, reaching beyond pleotelson margin, but minute; endopod flattened, leaf-like, with 5-6 distal setae.

Distribution. O Grove inlet, NW Iberian Peninsula, 0.3-5.9 m, among sea grasses Zostera marina and Z. noltii.

Remarks. Uromunna naherba sp. nov. can be immediately distinguished from the only species reported in the North East Atlantic, U. petiti, because the head anterior margin is straight in $U$. naherba (concave in $U$. petiti), and its pyriform pleotelson has lateral serrations (oval and without lateral serration in $U$. petiti).
Uromunna naherba sp. nov. resembles Uromunna serricauda Müller, 1992, reported from Malaysia, but in the latter species, the serration of the pleotelson reaches the distal tip, while in $U$. naherba, the denticles are only lateral. Moreover, U. serricauda has a suburopodal shelf, while $U$. naherba does not. The auxiliary claws on pereopods II to VII, as figured by Müller (1992), are much thinner than any other species of Uromunna, including $U$. naherba. The American species U. ubiquita (Menzies, 1952) also has serrations on lateral borders of the pleotelson, but the male pleopod I medial lobes distal margin is obliquely truncated, while in U. naherba the medial lobes are convex distally. Setae on the maxilliped epipod have not been reported in any other species of Uromunna. 


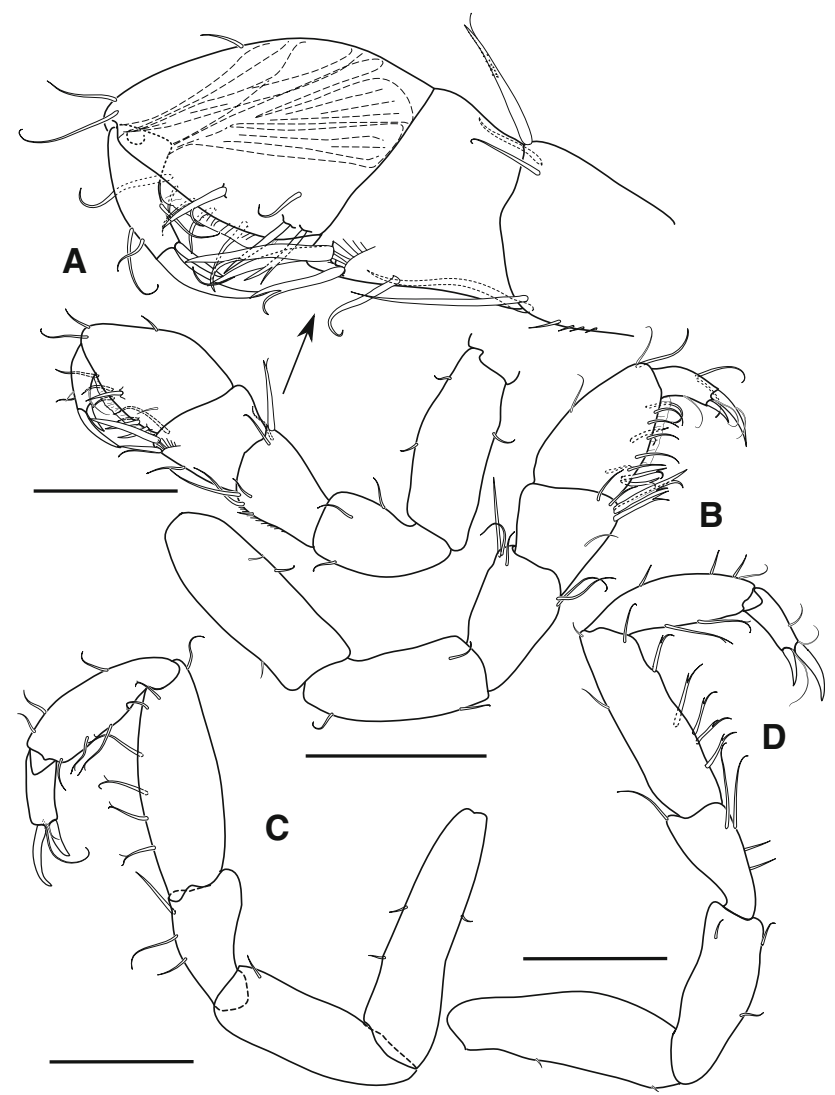

Fig. 4 Uromunna naherba sp nov. a Pereopod I, male; b pereopod I, female; c pereopod II, female; $\mathbf{d}$ pereopod II, male. a, $\mathbf{d}$ paratype AM P.88323.001. Scale bars $0.1 \mathrm{~mm}$

\section{Ecology}

The depth at the study sites ranged between 0.3 and $5.9 \mathrm{~m}$ at low tide (Table 1). Across the spatial scale of this study, salinity values were relatively low (range: 20-33\%o) and temperature of the bottom water ranged between 13.0 and $16.7^{\circ} \mathrm{C}$. Sediments were composed mainly of muddy sand $\left(\mathrm{Q}_{50}: 0.11-0.19 ; \mathrm{S}_{0}: 1.52-1.61\right)$, with relatively high percentages of fine sand $(0.125-0.25 \mathrm{~mm}$; up to $64.6 \%)$, very fine sand (0.063-0.125 mm; up to $47.9 \%)$ and silt/clay (0.063-0.125 mm; up to $61.6 \%)$. Carbonate content was relatively low (7.58-10.46\%). Organic matter percentages were high (up to $15.5 \%$ ). Uromunna naherba was most abundant (77.1 \% of total abundance) in mixed meadows, in sites located in the shelter area of the inlet having a depth of $0.3 \mathrm{~m}$ at low tide.

During the seasonal study, the temperature of the bottom water reached a minimum in March $\left(12.4^{\circ} \mathrm{C}\right)$ and a maximum in July $\left(25.2^{\circ} \mathrm{C}\right)$. Fine and very fine sand were the dominant granulometric fractions throughout the year (20.9-58.0 and 11.4-40.7\%, respectively). Silt/clay fraction showed more or less constant values, reaching the

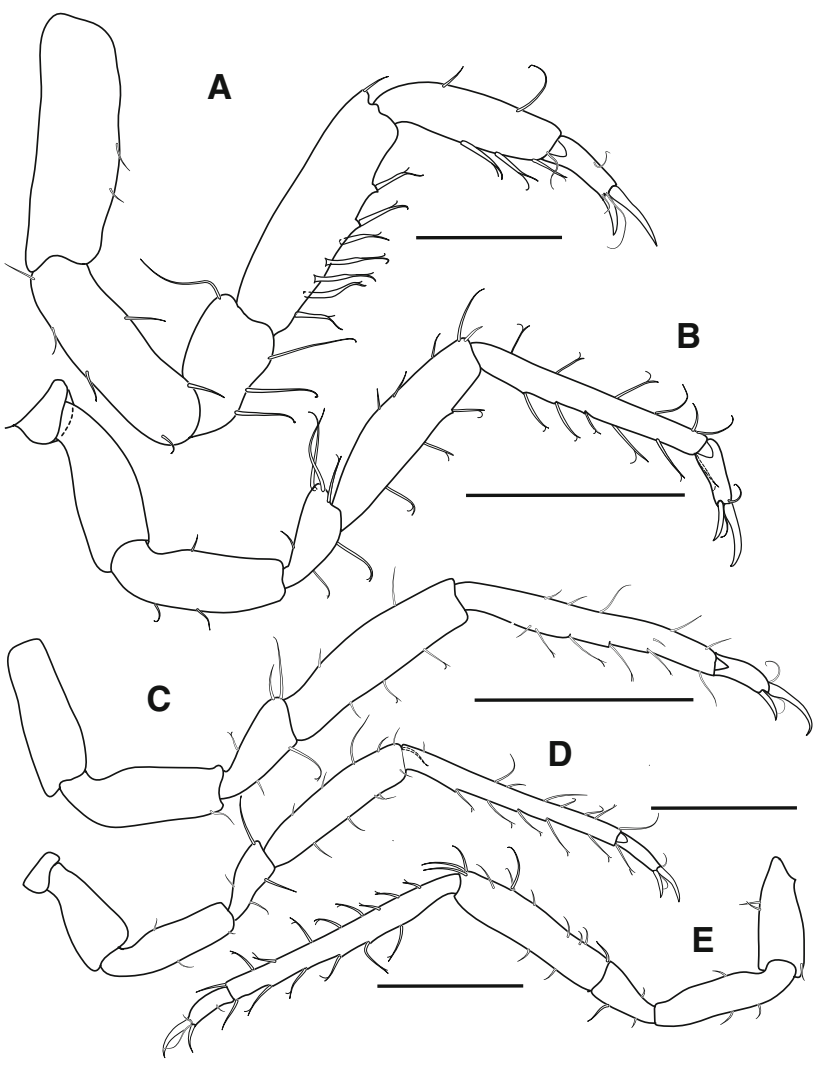

Fig. 5 Uromunna naherba sp nov, male paratype AM P88323.001. a-e Pereopods III-VII. Scale bars a, c, d $0.2 \mathrm{~mm}$, b $0.5 \mathrm{~mm}$, e $0.1 \mathrm{~mm}$

maximal content in January $(32.1 \%)$. Calcium carbonate and organic matter contents showed slight variation over the year, with maximal values in March (TOM $4.6 \%$; calcium carbonate $9.9 \%$ ). For detailed information on environmental variables in $\mathrm{O}$ Grove see Esquete et al. 2010, 2011.

The highest densities of Uromunna naherba sp. nov. were found during May (905.6 individuals $/ \mathrm{m}^{2}$ ), decreasing in July and being much lower than the rest of the sampling period. Although ovigerous females were found in all seasons, they represented the majority of the female specimens in May and July and were dominant in the population only in May (see Fig. 8; Table 2). The species was found associated with both the leaves and the rhizomes/sediment fraction of the eelgrasses. Nevertheless, it was more abundant on the rhizomes/sediment $(70.6 \%$ of specimens recorded in the seasonal study) than on the leaves $(29.4 \%)$, mainly due to the higher numbers and proportion of ovigerous females $(85.1 \%$ of all ovigerous females recorded (Fig. 9).

Significant differences $(P<0.001)$ in size were found between males $(\mathrm{TL}=0.99 \pm 0.15 \mathrm{~mm})$, non-ovigerous females $(\mathrm{TL}=1.15 \pm 0.16 \mathrm{~mm})$ and ovigerous females 


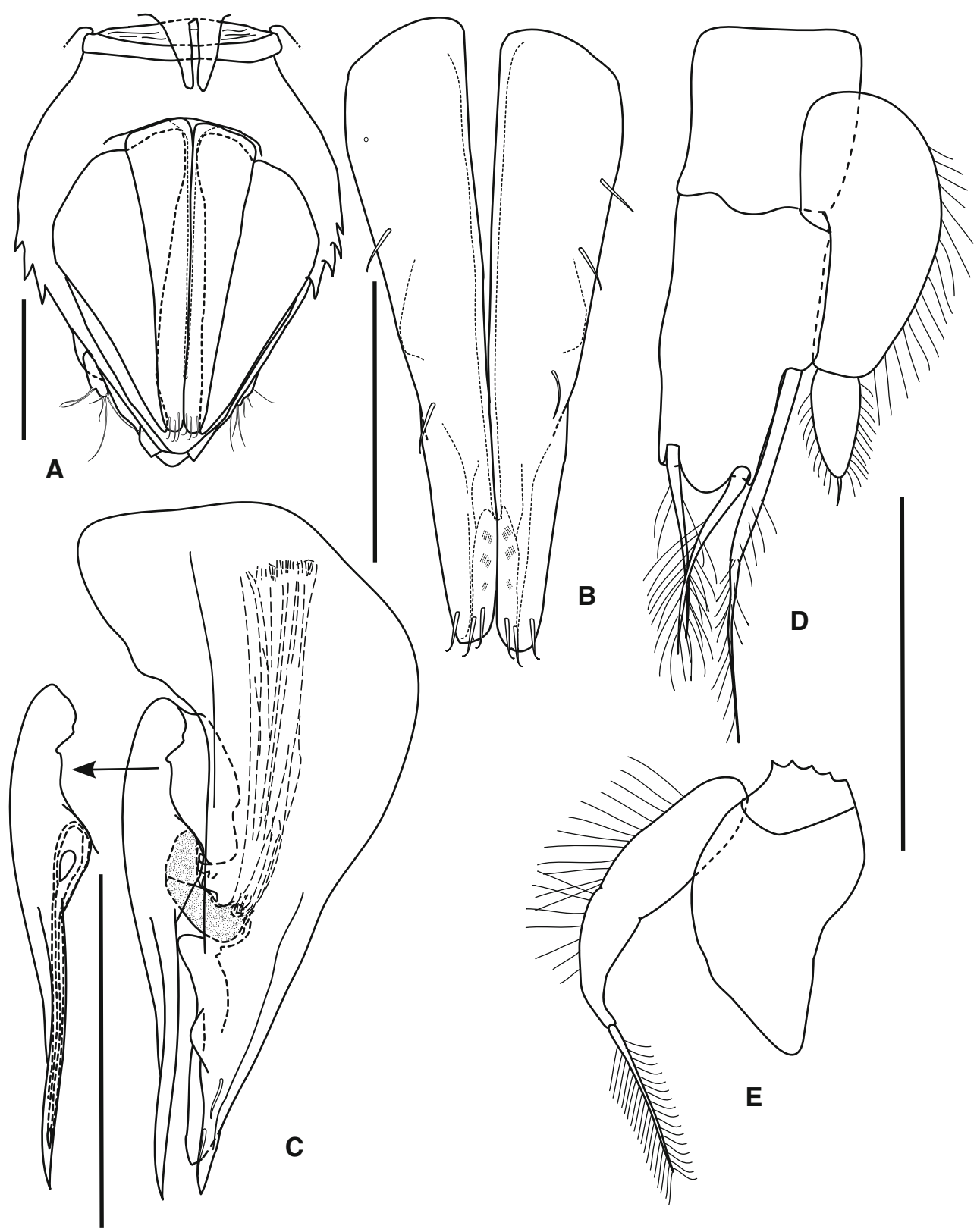

Fig. 6 Uromunna naherba sp nov, male paratype AM P88323.001 a Pleotelson, ventral view; b pleopods I; c pleopod II, exopod shaded; d pleopod III; e pleopods IV. Scale bars $0.1 \mathrm{~mm}$

( $\mathrm{TL}=1.23 \pm 0.09 \mathrm{~mm}$ ). On the other hand, no significant difference was found between the specimens on the leaves and on the rhizome/sediments. Non-ovigerous females $(P<0.05)$ were largest in March $(\mathrm{TL}=1.32 \pm 0.05)$ and smallest in January $(\mathrm{TL}=1.0 \pm 0.001)$. Males $(P<0.001)$ were largest in March $(\mathrm{TL}=1.17 \pm 0.09)$ and smallest in September (TL $=0.87 \pm 0.09)$. Ovigerous females did not show significant differences throughout the year nor between substrates. No significant correlation was found between size or density and the environmental variables studied.

\section{Discussion}

Systematics

Poore (1984) did not consider the subgenus Metamunna Fresi and Mazella in his list of species of Munna and Uromunna, thus omitting Munna (Metamunna) mediterranea Pierantoni, 1916 and Munna (Metamunna) similis Fresi and Mazella, 1971. Metamunna was defined by the absence of a ventral claw on the pereopods II to VI, but an inspection of the description reveals that Fresi and Mazella 


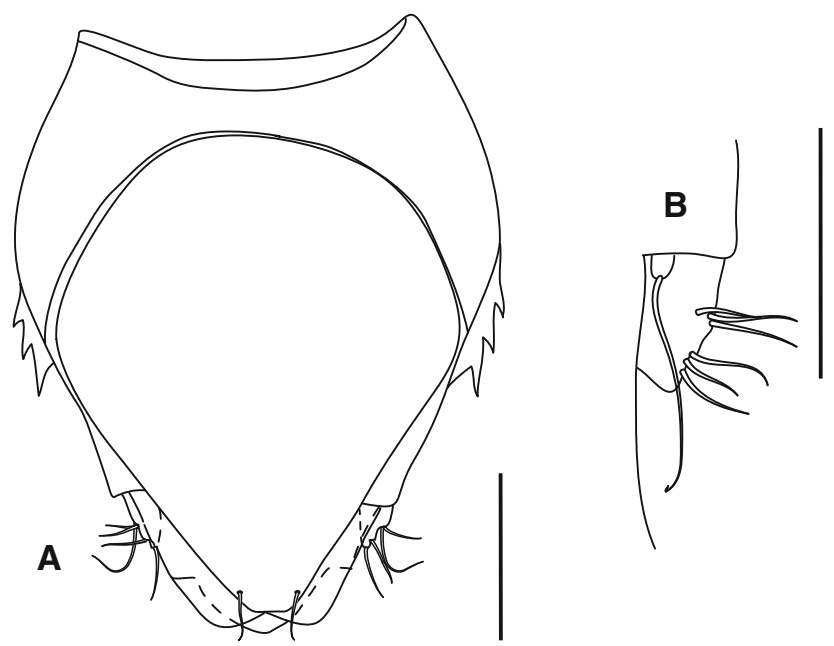

Fig. 7 Uromunna naherba sp nov. a Female paratype MNCN 20.04/ 9143 pleotelson ventral view; b uropod dorsal view. Scale bars a $0.1 \mathrm{~mm}$, b $0.05 \mathrm{~mm}$

(1971) did not consider a seta-like ventral claw of pereopods to be a claw. Nevertheless, the ventral claw shows a range of robustness across munnid species. Therefore, this feature is not valid for excluding the species mediterranea and similis from Uromunna. The generic-level name is preoccupied by Metamunna Tattersall 1906. Consequently, these two species are considered herein as new combinations $U$. mediterranea and $U$. similis, respectively. Uromunna peterseni was included within the genus by PiresVanin (1998), although it differs from the diagnoses given by Poore (opus cit.) in the length of pleopod III exopod, which reaches well beyond the endopod. Because the remaining characters are the same as Uromunna, this species is considered here as $U$. peterseni (Pires-Vanin, 1998) and the pleopod character is excluded from the generic diagnosis.

The species described here presents the general characters of Uromunna (sensu Poore 1984), with the exception of sexual dimorphism on pereopod II. This feature, however, has not been described for most species, so the validity of this character remains uncertain until further revision of the family is performed.

\section{Remarks on pleotelson anatomy of male}

Uromunna species have penes well separated from the proximal margin of pleopod I, as in the current species. Although this feature is not well illustrated in most munnids, Uromunna serricauda Müller, 1992 has the same ventral anatomy as $U$. naherba. Other species is suggestive of having an elongate "neck" region of the pleotelson posterior to pleonite 1 , but the position of the penes cannot be confirmed. In Munna spp., the penes reach to the
Table 1 Sampling stations (coordinates and depth), type of sediments and densities (individuals $/ 0.28 \mathrm{~m}^{2}$ ) found during the spatial scale study

\begin{tabular}{|c|c|c|c|c|c|c|}
\hline St & Coordinates & $\begin{array}{l}\text { Depth } \\
\text { (m) }\end{array}$ & Sediment & Males & Females & $\begin{array}{l}\text { Ovig } \\
\text { Fem }\end{array}$ \\
\hline D24 & $\begin{array}{c}42^{\circ} 29.01^{\prime} \mathrm{N} \\
8^{\circ} 50.25^{\prime} \mathrm{W}\end{array}$ & 0.8 & $\begin{array}{l}\text { Mud with } \\
\text { Z. Marina }\end{array}$ & 10 & - & - \\
\hline D27 & $\begin{array}{c}42^{\circ} 29.75^{\prime} \mathrm{N} \\
8^{\circ} 50.25^{\prime} \mathrm{W}\end{array}$ & 5.9 & $\begin{array}{l}\text { Mud with } \\
\text { Z. Marina }\end{array}$ & 7 & 5 & 2 \\
\hline D31 & $\begin{array}{l}42^{\circ} 28.25^{\prime} \mathrm{N} \\
8^{\circ} 50.75^{\prime} \mathrm{W}\end{array}$ & 0.3 & $\begin{array}{c}\text { Fine sand } \\
\text { with } Z \text {. } \\
\text { Marina }\end{array}$ & 36 & 14 & - \\
\hline D34 & $\begin{array}{c}42^{\circ} 27.75^{\prime} \mathrm{N} \\
8^{\circ} 50.25^{\prime} \mathrm{W}\end{array}$ & 0.3 & $\begin{array}{l}\text { Mud with } \\
Z \text {. Marina } \\
\text { and Z. } \\
\text { Noltii }\end{array}$ & 1 & - & 1 \\
\hline D35 & $\begin{array}{l}27.75^{\prime} \mathrm{N} \\
8^{\circ} 51.75^{\circ} \mathrm{W}\end{array}$ & 0.3 & $\begin{array}{c}\text { Fine sand } \\
\text { with } Z \text {. } \\
\text { Noltii }\end{array}$ & 9 & 3 & 1 \\
\hline D38 & $\begin{array}{l}42^{\circ} 27.25^{\prime} \mathrm{N} \\
8^{\circ} 52.25^{\circ} \mathrm{W}\end{array}$ & 0.3 & $\begin{array}{l}\text { Mud with } \\
\text { Z. Marina } \\
\text { and Z. } \\
\text { Noltii }\end{array}$ & 101 & 38 & 3 \\
\hline D39 & $\begin{array}{r}42^{\circ} 27.25^{\prime} \mathrm{N} \\
8^{\circ} 51.25^{\circ} \mathrm{W}\end{array}$ & 0.3 & $\begin{array}{l}\text { Mud with } \\
Z \text {. Marina } \\
\text { and } Z \text {. } \\
\text { Noltii }\end{array}$ & 102 & 59 & 4 \\
\hline D40 & $\begin{array}{r}42^{\circ} 27.25^{\prime} \mathrm{N} \\
8^{\circ} 51.75^{\circ} \mathrm{W}\end{array}$ & 0.3 & $\begin{array}{l}\text { Mud with } \\
\text { Z. Marina } \\
\text { and Z. } \\
\text { Noltii }\end{array}$ & 3 & - & - \\
\hline
\end{tabular}

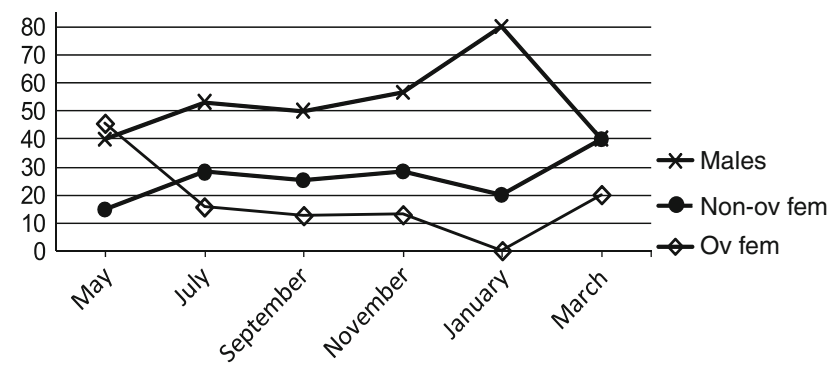

Fig. 8 Number of males, non-ovigerous and ovigerous females of $U$. naherba (individuals $/ 0.31 \mathrm{~m}^{2}$ ) per sample during the temporal scale study

proximal margin of pleopod I, as confirmed by Wilson (1980) for Munna stephenseni Gurjanova, 1933 and in Munna longipoda Teodorczyk and Wägele, 1994. Many species of Munna shown in lateral view have the proximal margin of pleopod I positioned close to pereonite I.

\section{Ecology}

Strong seasonal variation was found with respect to the density of adult Uromunna naherba sp. nov.: Densities 
Table 2 Data of densities (individuals $/ 0.31 \mathrm{~m}^{2}$ ) and total lengths $(\mathrm{TL} ; \mathrm{mm})$ per sample during the temporal scale study

\begin{tabular}{llrllllll}
\hline Month & Instar & $\mathrm{N}$ & $\%$ & $\mathrm{TL}$ & & & & \\
\cline { 5 - 8 } & & & & Mean & SD & Min & Max & Median \\
\hline May 98 & Females & 29 & 14.65 & 1.20 & 0.11 & 0.8 & 1.4 & 1.20 \\
& Males & 79 & 39.90 & 1.00 & 0.14 & 0.6 & 1.3 & 1.00 \\
& Ovig females & 90 & 45.45 & 1.20 & 0.09 & 1.0 & 1.5 & 1.20 \\
Jul 98 & Females & 9 & 28.12 & 1.09 & 0.21 & 0.8 & 1.4 & 1.20 \\
& Males & 17 & 53.12 & 1.05 & 0.12 & 0.9 & 1.2 & 1.00 \\
\multirow{5}{*}{ Sep 98 } & Ovig females & 5 & 15.62 & 1.22 & 0.04 & 1.2 & 1.3 & 1.20 \\
& Females & 2 & 25.00 & 1.05 & 0.21 & 0.9 & 1.2 & 1.05 \\
& Males & 4 & 50.00 & 0.87 & 0.09 & 0.8 & 1.0 & 0.85 \\
Nov 98 & Ovig females & 1 & 12.50 & 1.20 & - & 1.2 & 1.2 & 1.20 \\
& Females & 11 & 28.21 & 1.04 & 0.12 & 0.9 & 1.2 & 1.00 \\
& Males & 22 & 56.41 & 0.91 & 0.13 & 0.7 & 1.3 & 0.90 \\
\multirow{2}{*}{ Jan 99 } & Ovig females & 5 & 12.82 & 1.16 & 0.09 & 1.1 & 1.3 & 1.10 \\
& Females & 1 & 20.00 & 1.00 & - & 1.0 & 1.0 & 1.00 \\
Mar 99 & Males & 4 & 80.00 & 0.87 & 0.09 & 0.8 & 1.0 & 0.85 \\
& Females & 4 & 40.00 & 1.32 & 0.05 & 1.3 & 1.4 & 1.30 \\
& Males & 4 & 40.00 & 1.17 & 0.09 & 1.1 & 1.3 & 1.15 \\
& Ovig females & 2 & 20.00 & 1.30 & 0.00 & 1.3 & 1.3 & 1.30 \\
\hline
\end{tabular}

$S D$ standard deviation, $\min$ minimum, max maximum

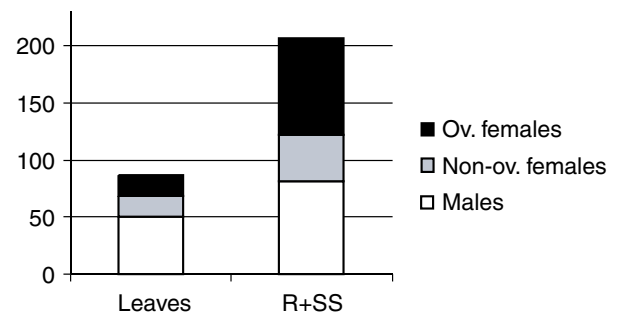

Fig. 9 Total number of males, non-ovigerous and ovigerous females of $U$. naherba found on the leaves and on the rhizomes and sediments $(\mathrm{RR}+\mathrm{SS})$ of the studied eelgrass meadow

reached a clear maximum during May and showed a second, but slight increase in November. As also observed for species of the same genus by García Guerrero and Hendrickx (2005), ovigerous females were present during the study period. The maximum percentage of ovigerous females was found in May, suggesting that young are released in summer. Other peracarid species has shown seasonal fluctuation in the Zostera meadows of O Grove, with maximum densities (including adults and juveniles) in late summer, coincident with the maximum enlargement of the leaves and thus the availability of substrate and food resources (Esquete et al. 2011, 2013). Indeed, seasonal fluctuations in the population in response to the maximum food availability are a common pattern for Asellota species: The observed seasonality is similar to that shown by other Uromunna species (García-Guerrero and Hendrickx, opus cit) as well as other Asellota in temperate latitudes (e. g. Jones and Naylor 1971; Jones 1974). Likewise, Asellota isopods in deep sea show a seasonal pattern, with reproduction maxima displaced to the winter in response to detritus deposition (Harrison 1988).

The largest specimens of both male and female $U . n a-$ herba were collected in March, while the smallest were collected in autumn and winter. Variation in the mean body size of the individuals within a population associated with variation in environmental conditions has frequently been reported for peracarids (e. g. De-la-Ossa-Carretero et al. 2010; Veloso et al. 2011; Rumbold et al. 2012). Likewise, seasonal variation in populations parameters presumably controlled to changes in temperature and/or food availability has been reported for other species of isopods. For instance, Jones and Naylor (1971) observed seasonal variation in the mean size of adult specimens of species of the asellote genus Jaera Leach 1814 owing to death of older individuals during the winter. Likewise, Luxmoore (1981) observed that growth in winter was significantly slower than in summer in the Antarctic species Paraserolis polita (Pfeffer, 1887) and considered this to be due to reduced food availability. In the case of U. naherba in O Grove, the above-mentioned decrease of food resources in the Zostera meadow in winter would lead to both (a) an increased mortality of older (and thus larger) individuals and (b) a slower individual growth, thus explaining the reduction of the mean body size of the individuals on the population.

The seasonal variations in both abundance and mean body size suggest that $U$. naherba is a semelparous species with an annual life cycle: Brooding females are not only significantly larger that non-brooding ones, but their body 
length is also rather constant throughout the year. These data indicate that the brooding stage is terminal. Furthermore, the peak of abundance of males that occurs at the end of winter is followed by a peak of brooding females. This is interpreted as a cohort of males that enter the adult stage, mate, and then die, followed by the largest (and thus oldest) females entering the brooding stage and dying after the offspring has been released.

Although specimens were found both on leaves and rhizome sediment fractions of the eelgrass meadow, adults of $U$. naherba seem to prefer rhizomes (70\% of the individuals were found in this fraction). This preference is more pronounced for females, particularly those carrying embryos ( $85.1 \%$ found on rhizomes), while the density of males was similar on both substrates. Two hypotheses could explain this vertical distribution: (a) Ovigerous females find shelter on the rhizome fraction, or (b) ovigerous females are not capable of climbing to the leaves. Several authors have observed that females scarcely feed or even do not feed at all when carrying eggs (e. g. Johnson 1976; Shafir and Field 1980; Shuster 1991). Assuming this condition, then ovigerous females would not need to climb in search of food, and the consequent lack of energy would, in turn, make their displacements difficult. The explanation for this vertical distribution appears to be a combination of both hypotheses.

Acknowledgments We are deeply grateful to the staff of the Adaptation of Marine Animals laboratory (University of Vigo, Spain) for their help with sampling at the O Grove inlet, and especially to our colleague P. Quintas for the sorting of the specimens. The present work has been developed in the Australian Museum (Sydney, Australia) and financed by the University of Vigo (Spain).

\section{References}

Amar R (1948) Un nouvelle espèce méditerranéenne du genre Munna (Isopoda, Asellota). Bull Mus Hist Nat Marseille 8:62-73

Boström C, Mattila J (1999) The relative importance of food and shelter for seagrass-associated invertebrates: a latitudinal comparison of habitat choice by isopod grazers. Oecologia 120:162-170

Carvacho A (1977) Isopodes de la mangrove de la Guadeloupe, Antilles Francaises. Stud Fauna Curaçao Other Caribb Isl 54(174): $1-2$

Castello J, Carballo JL (2001) Isopod fauna, excluding Epicaridea, from the Strait of Gibraltar and nearby areas (Southern Iberian Peninsula). Sci Mar 65:221-241

Coleman CO (2003) "Digital inking": how to make perfect line drawings on computers. Org Divers Evol 3:303

Dallwitz MJ (1980) A general system for coding taxonomic descriptions. Taxon 29:41-46

Dallwitz MJ, Paine TA, Zurcher EJ (2000) User's guide to the DELTA system, a general system for processing taxonomic descriptions. Edition 4.12. CSIRO, Canberra, Australia

De-la-Ossa-Carretero JA, Del-Pilar-Ruso Y, Giménez-Casalduero F, Sánchez-Lizaso JL (2010) Sensitivity of tanaid Apseudes latreillei (Milne-Edwards) populations to sewage pollution. Mar Environ Res 69:309-317

Esquete P, Moreira J, Troncoso JS (2010) First record of Perioculodes aequimanus (Crustacea: Amphipoda) in the north-east Atlantic, with remarks on taxonomic characters. Mar Biol Rec 3:e112

Esquete P, Moreira J, Troncoso JS (2011) Peracarid assemblages of Zostera meadows in an estuarine ecosystem (O Grove inlet, NW Iberian Peninsula): spatial distribution and seasonal variation. Helgol Mar Res 65:445-455

Esquete P, Bamber RN, Moreira J, Troncoso JS (2013) Pycnogonids (Arthropoda: Pycnogonida) in seagrass meadows: the case of $\mathrm{O}$ Grove inlet (NW Iberian Peninsula). Thalassas 29:25-33

Frankenberg D, Menzies RJ (1966) A new species of Asellote marine isopod Munna (Uromunna) reynoldsi (Crustacea: Isopoda). Bull Mar Sci 16:200-208

Fredette TJ, Diaz RJ, Van Montfrans J, Orth RJ (1990) Secondary production within a seagrass bed (Zostera marina and Ruppia maritima) in lower Chesapeake Bay. Estuar Coast 13:431-440

Fresi E, Mazzella L (1971) The genus Munna Krøyer (Isopoda: Asellota) in the Island of Ischia. Pubbl Stn Zool Napoli 39:44-63

García-Guerrero M, Hendrickx ME (2005) Fecundity and reproductive period of Paradella dianae and Uromunna sp. (Peracarida, Isopoda) associated with prop roots of Rhizophora mangle in a tropical coastal lagoon, SE Gulf of California, Mexico. Crustaceana 78:769-780

Gascón A, Mañé-Garzón F (1974) Una nueva especie del genero Munna (Isopoda, Asellota). Rev Biol Uruguay 2:63-69

Gurjanova EF (1933) Contribution to the Isopoda-fauna of the Pacific Ocean. I. New species of Valvifera and Flabellifera. Explor Mers URSS 17:87-106

Harrison K (1988) Seasonal reproduction in deep-sea Crustacea (Isopoda: Asellota). J Nat Hist 22:175-198

Hasegawa N, Hori M, Mukai H (2008) Seasonal changes in eelgrass functions: current velocity reduction, prevention of sediment resuspension, and control of sediment-water column nutrient flux in relation to eelgrass dynamics. Hydrobiologia 596:387-399

Johnson WS (1976) Population energetics of the intertidal isopod Cirolana harfordi. Mar Biol 36:351-357

Jones MB (1974) Breeding biology and seasonal population changes of Jaera nordmanni nordica Lemercier (Isopoda, Asellota). J Mar Biol Assoc UK 54:727-736

Jones MB, Naylor E (1971) Breeding and bionomics of the British members of Jaera albifrons group of species (Isopoda, Asellota). J Zool (London) 165:183-199

Just J, Wilson GDF (2004) Revision of the Paramunna complex (Isopoda : Asellota : Paramunnidae). Invertebr Syst 18:377-466

Kensley B (1980) A new species of Munna Kroyer from Nigeria (Crustacea: Isopoda: Munnidae). Proc Biol Soc Wash 93:136-140

Kensley B, Nelson WG, Schotte M (1995) Marine isopod biodiversity of the Indian River Lagoon, Florida. Bull Mar Sci 57:136-142

Kensley B (1977) New records of marine Crustacea Isopoda from South Africa. Ann S Af Mus 72:239-265

Kensley BF (2003) Marine isopod crustaceans from Easter Island. Pac Sci 57(3):287-317

Kussakin OG (1962) On the fauna of Munnidae (Isopoda, Asellota) from the far-eastern seas of the USSR. Trudy Zoologicheskogo Instituta Akademii Nauk SSSR 30:66-109

Leach WE (1814) Crustaceology. The Edinburgh Encyclopaedia 7:383-437

Luxmoore RA (1982) The reproductive biology of some serolid isopods from the Antarctic. Pol Biol 1:3-11

Luxmoore RA (1981) Moulting and growth in serolid isopods. J Exp Mar Biol Ecol 56(1):63-85

Menzies RJ (1952) Some marine asellote isopods from northern California, with descriptions of nine new species. Proc US Nat Mus 102:117-159 
Menzies RJ (1962) The zoogeography, ecology, and systematics of the Chilean marine isopods (Reports of the Lund University Chile Expedition 1948-49, no. 4). Lunds Universitets Årrskrifter NF Avd 257 (11):1-162

Miller MA (1941) The Isopod Crustacea of the Hawaiian Islands, II. Asellota. Occ Pap Bishop Mus 16:305-320

Nordenstam A (1933) Marine Isopoda of the Families Serolidae, Idotheidae, Pseudidotheidae, Arcturidae, Parasellidae and Stenetriidae Mainly from the South Atlantic. Further zool. Results Swerf Antarct Exped 3(1):1-248

Pfeffer G (1887) Die Krebse von Süd-Georgien nach der Ausbeute der Deutschen Station 1882-83.- Jahrbuch der Hamburgischen Wissenschaftlichen Anstalten 4:43-150

Pierantoni U (1916) Sopra un nuovo Isopode marino del Golfo di Napoli (Munna mediterranea n. sp.) Pubbl Staz zool Napoli $1: 147-154$

Pires AMS (1985) The occurrence of Munna (Isopoda, Asellota) on the Southern Brazilian Coast, with a description of two new species'). Crustaceana 48:64-7

Pires-Vanin AMS (1998) Malacostraca-Peracarida. Marine Isopoda. Anthuridea, Asellota (pars), Flabellifera (pars), and Valvifera. In: Young PS (ed) Catalogue of Crustacea of Brazil. Rio de Janeiro, Museu Nacional, Brazil, pp 605-624

Poore GCB (1984) Redefinition of Munna and Uromunna (Crustacea: Isopoda: Munnidae), with descriptions of five species from coastal Victoria. Proc R Soc Vic 96:61-81

Poore GCB (2002) Crustacea: Malacostraca: Syncarida, Peracarida: Isopoda, Tanaidacea, Mictacea, Thermosbaenacea, Spelaeogriphacea, vol 19.2A. Zoological Catalogue of Australia. CSIRO Publishing, Australia, Melbourne

Robertson PB (1978) A new species of asellote marine isopod, Munna (Uromunna) hayesi (Crustacea: Isopoda) from Texas. Contrib Mar Sci 21:39-46

Rumbold CE, Obenat SM, Spivak ED (2012) Life history of Tanais dulongii (Tanaidacea: Tanaidae) in an intertidal flat in the southwestern Atlantic. J Crust Biol 32:891-898
Sars GO (1897) Isopoda. Part V, VI. Idoteidae, Arcturidae, Asellidae, Ianiridae, Munnidae. An account of the Crustacea of Norway with short descriptions and figures of all the species, vol 2 . Bergen Museum, Bergen, Norway, pp 81-116

Sars GO (1905) An account of Crustacea of Norway 5

Schultz GA (1979) Louisiana and Panama Canal locations and ecology of Munna (Pangamunna nov. subgen.) reynoldsi Frankenberg and Menzies (Isopoda: Asellota). Proc Biol Soc Wash 92:577-579

Shafir A, Field JG (1980) Importance of a small carnivorous isopod in energy transfer. Mar Ecol Prog Ser 3:203-215

Shuster SM (1991) The ecology of breeding females and the evolution of polygyny in Paracerceis sculpta, a marine isopod crustacean. In: Bauer RT, Martin JW (eds) Crustacean sexual biology. Columbia University Press, New York/Oxford, pp 91-110

Tattersall WM (1906) The marine fauna of the coast of Ireland. V. Isopoda. Fish Irel Sci Invest 1904:53-141

Thomson JM (1946) New Crustacea from the Swan river estuary. J proc R Soc West Aust 30:35-53

Veloso VG, Neves G, de Almeida Capper L (2011) Sensitivity of a cirolanid isopod to human pressure. Ecol Indic 11:782-788

Wilson GD (1980) New insights into the colonization of the deep sea: systematics and zoogeography of the Munnidae and the Pleurogoniidae comb. nov. (Isopoda; Janiroidea). J Nat Hist $14: 215-236$

Wilson GDF (1989) A systematic revision of the deep-sea subfamily Lipomerinae of the isopod crustacean family Munnopsidae. Bull Scripps Inst Oceanogr 27:1-138

Wolff TL, Brandt A (2000) Carribbean species of Munnidae, Paramunnidae and Santiidae (Isopoda: Asellota). Steenstrupia 25:121-146

Zar JH (1999) Biostatistical analysis, 4th edn. Pearson Education, Englewood Cliffs 